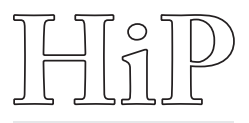

Historia i Polityka

Nr $13(20) / 2015$, ss. 31-46

ISSN 1899-5160

www.hip.umk.pl

DOI: http://dx.doi.org/10.12775/HiP.2015.002

Maryana PROKOP

Uniwersytet Mikołaja Kopernika w Toruniu

\title{
Demokratyczno-autorytarna hybryda: redefinicja kategorii teoretycznej
}

\section{The Democratic-Authoritarian Hybrid: Redefine the Theoretical Category}

\begin{abstract}
In the article the author is raising the issues of theoretical and methodological background of research studies on hybrid regimes which are located between democracy and authoritarianism. The author is trying to respond to the following research problem: to what extent the abstract hybrid regimes category can be seen as a new type of political regimes and to what extent it should be regarded only as one of the steps of the transition. Considering the research problem presented in the introduction, the author came to the conclusion that hybrid systems in some cases should be considered as stages of the system transition; however, the fact that long-term balance between democracy and authoritarianism can become the basis for determining the hybrid regimes as a new type of political systems should not be negated.
\end{abstract}

Keywords: hybrid regimes, democracy, authoritarianism, transition

Słowa kluczowe: reżimów hybrydalne, demokracja, autorytaryzm, tranzycja

\section{Wstęp}

Nasilenie się procesów demokratyzacji we współczesnym świecie (w XX w.) przyczyniło się do wzrostu zapotrzebowania, na wytworzenie narzędzi które umożliwią analizę danego zjawiska. Jednakże nie wszystkie procesy tranzycji zakończyły się demokratyzacją, powstała więc konieczność wypracowania narzędzi badań systemów, których nie możemy jednoznacznie zaliczyć ani do demokracji, ani do autorytaryzmu. Wieloletnie badania dotyczące tych zagadnień spowodowały powstanie wielu pytań, różnorodnych hipotez, podjęcia prób wyjaśnienia, dlaczego jedne państwa z powodzeniem konstatują przejście do reżimów demokratycznych, drugie borykają się z tym przez lata.

Proces transformacji w krajach byłego ZSRR, trwający w ciągu ostatnich dwudziestu lat, spowodował liberalizację oraz demokratyzację reżimów autorytarnych. Jednocześnie doprowadził do powstania swoistego problemu: nowopowstałych 
reżimów, w większości krajów postradzieckich, nie można było jednoznacznie zaliczyć do modelowych rozwiązań reżimów politycznych. Kraje te posiadają cechy kilku typów idealnych, ponieważ balansują na granicy demokracji i autorytaryzmu. W 1996 r. amerykański badacz Larry Diamond konstatując koniec „trzeciej fali” demokratyzacji, stwierdził, że główną przyczyną tego stanu rzeczy, stało się przejście państw nie do demokracji liberalnej, lecz do tzw. stanów pośrednich reżimów politycznych, znajdujących się na continuum demokracji i autorytaryzmu ${ }^{1}$.

Ukształtowało się przekonanie że proces tranzycji systemowej w niektórych przypadkach trwa dłużej, a państwo potrzebuje więcej czasu by „pozbyć” się starego systemu i przyjąć nowy. Tego typu zjawisko określono mianem stanów pośrednich tzw. reżimów hybrydalnych (hybryda demokratyczno-autorytarna, hybryda autorytarno-demokratyczna ${ }^{2}$ ). Celem artykułu jest próba analizy kategorii hybrydy demokratyczno-autorytarnej ${ }^{3}$, przez naszkicowanie teoretycznych i metodologicznych podstaw badań nad reżimami hybrydalnymi. Główny problem badawczy dotyczył odpowiedzi na pytanie, w jakim stopniu abstrakcyjna kategoria reżimów hybrydalnych (hybrydy demokratyczno-autorytarnej), może być postrzegana jako nowy typ reżimów politycznych, a w jakim należy ją traktować wyłącznie jako jeden z etapów tranzycji systemowej?

\section{Pojęcie oraz istota reżimów hybrydalnych}

Badania nad continuum między demokracją a autorytaryzmem nie należą do novum, lecz nadal są bardzo aktualne ze względu na wpływ, jaki mają światowe wydarzenia polityczne na państwa „przemieszczające” się między typami idealnymi. Pojęcie reżimów hybrydalnych uwzględnia w swojej klasyfikacji wskaźnik demokracji (Democracy Index) Economist Intelligence Unit, jednostkę badawczą wprowadzoną przez ekspertów tygodnika The Economist, opisującą stan demokracji w 167 krajach świata. Indeks wyznacza się w oparciu o sześćdziesiąt wskaźników pogrupowanych w pięciu różnych kategoriach: proces wyborczy i pluralizm, swobody obywatelskie, funkcjonowanie administracji publicznej, partycypacja polityczna oraz kultura polityczna. Według tych założeń dokonano podziału na: demokracje pełne (liberalne), demokracje wadliwe (wyborcze), systemy hybrydalne,

\footnotetext{
${ }^{1}$ L. Diamond, Is the Third Wave Over?, Journal of Democracy 1996, vol. 7, nr 3, s. 20-37.

${ }^{2}$ Nazewnictwo hybrydy kształtuje się na zasadzie zależności od tego, jakie cechy istotnościowe typu idealnego przeważają.

${ }^{3}$ Przyjęłam tę kolejność, ze względu na fakt, że reżimy te zmierzają w kierunku demokracji.
} 
systemy autorytarne (autorytaryzm skonsolidowany) ${ }^{4}$. Określenie reżimów hybrydalnych pojawiło się także w raportach amerykańskiej fundacji Freedom House, która systematycznie prowadzi monitoring przemian politycznych na przestrzeni postradzieckiej. Badania oparto na następujących kryteriach: jakość rządzenia na poziomie centralnym oraz lokalnym, proces wyborczy, rozwój społeczeństwa obywatelskiego, niezależność mediów, jakość i niezależność sądownictwa oraz poziom korupcji. Każdy z tych wskaźników posiada gradacje od 1 (maksymalnie demokratyczny) do 7 (maksymalnie autorytarny). Na podstawie badań zmiennych Freedom House wyodrębnił: skonsolidowane demokracje (średnia wszystkich wskaźników waha się między 1,00 a 2,99), na wpół skonsolidowane demokracje $(3,00-3,99)$ reżimy przejściowe lub hybrydalne $(4,00-4,99)$, na wpół reżimy autorytarne $(5,00-5,99)$ oraz skonsolidowane reżimy autorytarne $(6,00-7,00)^{5}$.

Kategoria reżimów hybrydalnych najczęściej jest stosowana w odniesieniu do ewolucji zachodzącej w krajach Europy Wschodniej w szczególności w byłych republikach ZSRR. Jako jeden z pierwszych pojęcie „reżimu hybrydalnego” użył węgierski socjolog Edward Hankiss by określić system komunistycznych Węgier za czasów rządów Jánosa Kadara ${ }^{6}$. W wśród badaczy reżimów hybrydalnych należy również wyróżnić Gulermo O’Donnella ${ }^{7}$ Larriego Diamonda ${ }^{8}$ oraz Philipa C. Schmittera9 ${ }^{9}$ Uważa się, że to oni dokonali pierwszych prób interpretacji reżimów hybrydalnych oraz wprowadzili pojecie do naukowego leksykonu nauk politycznych. Problem ten omawiany był także w pracach polskich badaczy m.in.: Andrzeja Antoszewskiego, Ryszarda Herbuta ${ }^{10}$ oraz Romana Bäckera ${ }^{11}$. Jednak-

${ }^{4}$ The Economist Intelligence Unit's Index of Democracy, http://www.economist.com-/media/ pdf/DEMOCRACY_INDEX_2007_v3.pdf, odczyt z 3.03.2012, s. 1-11.

5 Methodology Freedom House, https://freedomhouse.org/report/nations-transit-2012/methodology\#.VSWnR9ysUXN, odczyt z 20.03.2014.

${ }^{6}$ E. Hankiss, The Second Society is There an Alternative Social Model. Emerging in Contemporary Hungary?, Social Research 1988, 55:1/2, s. 26-35.

7 G. O’Donnell, Delegative Democracy, Journal of Democracy 1996, vol. 5 (1), s. 55-69; G. O'Donnell, P.C. Schmitter, Transitions from Authoritarian Rule: Tentative Conclusions about Uncertain Democracies, Baltimore 1986.

${ }^{8}$ L. Diamond, op. cit.; idem, Development Democracy: Toward Consolidation, Baltimor 1999; idem, Election without Democracy: Thinking about Hybrid Regimes, Journal of Democracy 2002, vol. 13 , nr 2, s. 20-37.

9 P.C. Schmitter, T.L. Karl, What Democracy is... and is Not, Journal of Democracy 1991, vol. 2, nr 3, s. 77-88.

${ }^{10}$ A. Antoszewski, R. Herbut, Systemy polityczne wspótczesnego świata, Warszawa 2001; eidem, Systemy polityczne wspótczesnej Europy, Gdańsk 2006;

${ }^{11}$ R. Bäcker Reżimy hybrydalne, [w:] Studia nad wspótczesnymi systemami politycznymi. Podmioty i procesy demokratyczne: ksiega dedykowana profesorowi Andrzejowi Antoszewskiemu, red. J. Juchnowski, R. Wiszniowski, t. 1, Toruń 2014, s. 37-46. 
że znacznie częściej poruszany jest przez zagranicznych badaczy ${ }^{12} \mathrm{~m}$.in.: Lucana Way'a, Stevena Levitskiego ${ }^{13}$, Wolfganga Merkla ${ }^{14}$, Genadija Szypunowa ${ }^{15}$, Mykołe Riabczuka ${ }^{16}$, Dmitrija Furmana ${ }^{17}$, Jana Holzera, Stanislava Balika ${ }^{18}$.

Problem z jednoznacznością w interpretacji zagadnienia reżimów hybrydalnych spowodował pojawienie się wielu koncepcji oraz prób ich operacjonalizacji przez terminy pokrewne. Badacze, analizując reżimy państw znajdujących się między demokracją a autorytaryzmem, posługują się różnymi pojęciami: „niepełna demokracja”, „demokracja kierowana”, „półdemokracja”, „demokracje delegatywne”, „demokracje nieliberalne”, „półautorytarny reżim”, „konkurencyjny autorytaryzm”, „szara strefa”, „reżim kierowanego pluralizmu”, „reżim dominującej władzy”, „anokracja” ${ }^{19}$, „reżimy hybrydalne”. Analiza wyżej wymienionych podejść daje podstawę twierdzić, że z punktu widzenia wyodrębnienia cech istotnościowych dla reżimów pośrednich, koncepcje te można traktować, jako kategorie pokrewne.

${ }^{12}$ W literaturze anglojęzycznej możemy zaobserwować, z jednej strony wielość prac na temat systemów hybrydalnych, z drugiej w pracach tych widoczne jest rozproszenie, gdyż zagadnieniem hybrydalności reżimów państwowych zajmuje się większa rzesza badaczy. W konsekwencji przyczyniło się to do powstania wielu koncepcji, niekiedy znacznie różniących się od siebie oraz sposobów definiowania przyczyn przynależności państw do strefy continuum między demokracją a autorytaryzmem.

13 S. Levitsky, L.A. Way, The Rise of Competitive Authoritarianism, Journal of Democracy 2002, vol. 13, nr 2, s. 5-17; eidem Competetive Authoritarianism, Hybrid Regimes after the Cold War, New York 2010.

${ }_{14}$ В. Меркель, А. Круассан, Формальные и неформальнысе институть в дефектных демокpатиях (II), Полис 2002, nr 2, s. 6-17.

${ }^{15}$ Г. Шипунов, Теоретико-методологічні засади аналізу гібридних політичних режимів: український контекст, Наукові записки [Наиіонального університету „Острозька академіл”], Політичні науки 2008; idem, Методологічні засади використання категорї̈ „політичний режим" в контексті дослідження посткомуністичних трансформащій, Вісник СевНТУ: зб. наук. пр. Серія: Політологія, Севастополь 2011, Вип. 123/2011.

${ }^{16}$ M. Riabczuk, Agony of a "Blackmail state": Rise and (Possible) Fall of Post-Soviet Semi-Authoritarian Regims, [w:] Ukraine on Its Meandering Path between East and West, red. A.N. Lushyckyj, M. Riabchuk, Frankfurt am Main 2009.

17 А. Фурман, Политическая система иовременной России и её жезненный цъькл, Свободная мысль 2003, nr 11; s. 2-10; idem, Аивергенция политических систем на постсоветском пространстве, Свободная мысль nr 10, 2004, s. 14-24; idem, Общее и особенное в политическом развитии России и других стран СНГ, [w:] Пути российского посткоммунизма, red. М. Аипман, А. Рябов, Москва 2007, s. 234-273; idem, Авижение по спирали. Политическая система России в рядудругих систем, Москва 2010.

18 J. Holzer, S. Balik, Postkomunistyczne reżimy niedemokratyczne. Badania nad przemianami teorii politycznej w okresie po transformacji ustrojowej, Kraków 2009.

19 Anokracja - reżim pozbawiony wewnętrznej spójności, nieposiadający jednoznacznych, dobrze utrwalonych (zinstytucjonalizowanych) i obejmujących cały kraj cech demokracji lub autokracji, A. Kondratowicz Demokracja a jakość rządzenia, [w:] Jakość rządzenia w Polsce. Jak ją badać, monitorować i poprawiać?, red. J. Wilkin, Warszawa 2013, s. 74. 
W celu uporządkowania koncepcji reżimów hybrydalnych ukraiński badacz G. Szypunow zaproponował zgrupowanie poglądów na temat reżimów hybrydalnych $^{20}$. Do pierwszej grupy zaliczył badaczy, którzy uważają, że reżimy z jednej strony, posiadają proceduralne minimum demokracji (np. cyklicznie odbywają się w jakimś stopniu uczciwe i konkurencyjne wybory), z drugiej - odbywają się też regularne naruszenia (np. praw i swobód obywatela, lekceważy się konstytucyjne ograniczenia władzy, podobnie jak w reżimach autorytarnych). Określono je jako „niepełne”, „ograniczone” lub „demokracje z przymiotnikiem” („niepełna demokracja”, „demokracja delegatywna”, demokracja kierowana”, „demokracja nieliberalna”, „defektywna demokracja”, „imitująca demokracja”). Do tej grupy należy zaliczyć poglądy: G. O'Donnella, Fareeda Zakariee ${ }^{21}$, W. Merkela, Andreasa Schedlera $^{22}$, P.C. Schmittera, D. Furmana).

Przedstawiciele drugiej grupy negują sposób określania reżimów hybrydalnych za pomocą pojęcia „demokracji z przymiotnikami”. W ich opinii nazwanie ich „nieliberalnymi” lub „defektywnymi” jest dużym nadużyciem. Zamiast tego rozpatrują reżimy te jako nowy, zliberalizowany lub zdemokratyzowany autorytaryzm. Reprezentantami tej grupy są: L. Way, S. Levitski, Phillip Roeder ${ }^{23}$, Marina Ottawey ${ }^{24}$, M. Riabczuk.

Z kolei przedstawiciele trzeciej grupy, podtrzymują stanowisko, iż podejście do badanych reżimów przez różnego rodzaju „wariacje” na temat autorytaryzmu bądź demokracji, odzwierciedla proces ewolucji tych systemów, gdyż stan przejściowy między demokracją a pełną dyktaturą jest dla nich najbardziej charakterystycznym. Dlatego przedstawiciele tej grupy rezygnują z używania kategorii „demokracji” lub „autorytaryzmu”. W kontekście badań nad reżimami używają w swojej klasyfikacji takich pojęć jak: „kreowany pluralizm”, „reżim dominującej władzy”, „szara strefa”, „reżimy hybrydalne” (L. Diamond, Harley Balzer ${ }^{25}$, Thomas Carothers ${ }^{26}$, A. Antoszewski, R. Herbut, W. Żebrowski).

20 Zob. Г. Шипунов, op. cit., s. 92-98.

${ }^{21}$ F. Zakaria, The Rise of Illiberal Democracy, Foreign Affairs 1997, vol. 76, nr 6, s. 22-44.

22 A. Schedler, The Menu of Manipulation, Journal of Democracy 2002, vol. 13, nr 2, s. 91-107.

${ }_{23}$ G. Ph. Roeder, Varieties of Post-Soviet Authoritarian Regimes, Post Soviet Affairs 1994, vol. 10, nr 1, s. 61-101.

${ }_{24}$ М. Оттауэй, Демократия: только на половину, Трудности перехода: демократия в России, Москва 2004.

${ }_{25}$ Х. Балзер, Управляемый плюрализм: формирующийся режим В. Путина, Общественные науки и современность 2004, nr 2, s. 46-59.

26 Th. Carothers, How Democratizes Emerge. The "Sequencing" Fallacy, Journal of Democracy 2007, vol. 18, nr 1, s. 12-22. 


\section{Analiza wybranych koncepcji reżimów hybrydalnych}

Jak już zostało zasygnalizowane, wielu badaczy podjęło się analizy reżimów hybrydalnych. Nie jest możliwe w ramach jednej publikacji wyjaśnienie wszystkich ujęć, w związku z tym podjęłam się przedstawienia zarysu niektórych z nich.

Polscy badacze A. Antoszewski i R. Herbut opisując zagadnienie systemów politycznych państw balansujących między demokracją a autorytaryzmem, posługują się pojęciem „szarej strefy” politycznej. Do najważniejszych przyczyn przynależności do niej, zaliczają trudną sytuację ekonomiczną, stan kultury politycznej oraz opóźnienia w rozwoju politycznym (rozumiane jako brak uwzględniającego faktyczne podziały społeczne systemu partyjnego oraz brak społeczeństwa obywatelskiego ${ }^{27}$. Wskaźnik ekonomicznej nieudolności oraz opóźnienia w rozwoju politycznym wyróżnia także G. O’Donnell twierdząc, że na przynależność państwa do krajów demokracji delegatywnej (demokracji przemieszczającej) ma wpływ głęboki socjalno-ekonomiczny kryzys, który jest efektem przejścia od reżimu autorytarnego. W tym przypadku stabilne środowisko polityczne wiąże się ze stabilnością ekonomiczną państwa, również dlatego w krajach demokracji delegatywnej, podniesienie poziomu życia obywateli jest głównym aspektem programów przedwyborczych partii i kandydatów na urząd prezydenta ${ }^{28}$.

Zdaniem Th. Carothersa przebywanie w „szarej strefie” może być skutkiem nieodpowiedniego pluralizmu (feckless pluralism) lub dominacji określonej politycznej sily (dominant-power politics). W przypadku nieodpowiedniego pluralizmu w społeczeństwie pozostaje pewien poziom politycznych swobód, odbywają się cykliczne wybory, u władzy są różnorodne ugrupowania polityczne. Jednocześnie udział w polityce społeczeństwa sprowadza się tylko do aktu głosowania, a ugrupowania polityczne walczące o władze są skorumpowane i nieosiągalne dla zwykłych obywateli. Swoją drogą w reżimach dominującej politycznej siły, mimo zachowania demokratycznych standardów i uczestnictwa społeczeństwa, nie dochodzi do wymiany elity rządzącej, co w konsekwencji doprowadza do zatarcia granicy między partią rządzącą (jej liderem) a państwem. Z rozważań Th. Carothersa wynika, że na przynależność państwa do strefy continuum między demokracją a autorytaryzmem ma wpływ przede wszystkim czynnik wielości i różnorodności systemu partyjnego. Gdy zasada pluralizmu nie jest realizowana, wymiana władzy i akt głosowania stają się tylko formalnością. Elity władzy nie są tworzone przez różnorodne ugrupowa-

27 A. Antoszewski, R. Herbut, Systemy polityczne współczesnego..., s. 34-38; A. Antoszewski, Przejście ku demokracji: analiza przypadku Polski, [w:] Transformacja w Polsce i na Ukrainie. Wybrane aspekty, red. A. Antoszewski, A. Kolodii, K. Kowalczyk, Wrocław 2010, s. 11-21.

28 G. O’Donnell, Delegative..., s. 55-69. 
nia polityczne, a społeczeństwo staje się apatyczne i nie interesuje się istniejącą rzeczywistością polityczną państwa ${ }^{29}$. Przyczynia się to do tego, iż obok demokratycznych zasad w państwie są stosowane narzędzia niedemokratyczne, a to z kolei powoduje, iż kraj nie ewoluuje z jednego typu idealnego w drugi, gdyż posiada cechy istotnościowe zarówno jednego i drugiego reżimu politycznego, co daje podstawy twierdzić, że mamy do czynienia z hybrydami owych reżimów.

Kolejnym elementem reżimów hybrydalnych według A. Antoszewskiego i R. Herbuta jest koncentracja władzy w rękach głowy państwa pochodzącej z rywalizacyjnych wyborów ${ }^{30}$. G. O'Donnell uważa, że reżimy te cechują się niską instytucjonalizacją władzy oraz tym, iż wygrana w wyborach daje zwycięzcy prawo rządzić według swego uznania. Wskaźnik ten stał się głównym kryterium selekcji demokracji według O’Donnella na demokrację elektoralną i pseudodemokrację (quasidemokrację). Pierwsza charakteryzuje się cyklicznymi, uczciwymi i rywalizacyjnymi wyborami oraz zabezpieczeniem minimum swobód obywatelskich. Pseudodemokracja (półdemokracja) bliska jest demokracji elektoralnej w stosunku do poziomu pluralizmu, konkurencyjności systemu partyjnego i swobód obywatelskich. Natomiast stosowana jest wyborcza dominacja "partii władzy”, pozbawienie realnego znaczenia politycznego wyborów do parlamentu, zablokowanie możliwości tworzenia i działania opozycji oraz naruszenia praw człowieka ${ }^{31}$.

P.C. Schmitter z kolei rozróżnia dwa typy reżimów hybrydalnych: demokratura i dyktoblanda. Jego zdaniem powstają one w wyniku ewolucji od jednego ku drugiemu typowi reżimu politycznego, gdy poprzedni rządzący próbują chronić swoje interesy drogą autorytarnych metod w nowym reżimie. W przypadku przeprowadzania liberalizacji bez demokratyzacji (przedstawienia obywatelom niektórych praw, które nie ograniczają możliwości rządzących) mamy do czynienia z dyktoblandami. Demokratyzacji nie towarzyszy bowiem liberalizacja (wybory są przeprowadzane, lecz przy gwarantowanej wygranej partii władzy, stosowane są ograniczenia wobec partii opozycjii) ${ }^{32}$. P.C. Schmitter dokonuje rozróżnienia (oddzielenia od siebie) czynnika demokratyzacji i liberalizacji (oba czynniki są istotne w badaniach nad reżimami hybrydalnymi), natomiast analiza pod kątem liberalizacji bez demokratyzacji bądź demokratyzacji bez liberalizacji wydaje się być istotna w kontekście tworzenia typologii reżimów hybrydalnych.

A. Antoszewski i R. Herbut, zaznaczają, że pobyt państw w tej strefie, choć może się przedłużyć, jest przejściowy. Ich zdaniem w efekcie ewolucji politycznej

\footnotetext{
29 Th. Carothers, op. cit., s. 5-19.

30 A. Antoszewski, R. Herbut, Systemy polityczne współczesnego..., s. 34-38.

31 G. O’Donnell, Delegative..., s. 55-69.

32 P.C. Schmitter, T.L. Karl, op. cit., s. 75-88.
} 
może dojść do dołączenia państw znajdujących się na osi continuum do demokracji lub autorytaryzmu. Czynnikiem, który przesądza kierunek rozwoju politycznego państw demokracji delegatywnej jest nienapotykająca na poważniejsze ograniczenia wola jednostki lub wąskiej grupy albo nieprzewidywalne wydarzenia. Hasła nacjonalistyczne oraz populistyczne, do których odwołują się przywódcy polityczni w krajach „szarej strefy” zapewniają im poparcie (nierzadko wyrażane w manifestacyjny sposób), nie sprzyja to konkurencyjności programów politycznych odwołujących się do interesów poszczególnych grup społecznych. Dopóki jednak zasada wyłaniania władzy przez wolne i uczciwe wybory nie przestanie być realizowana, dopóty istnieją szanse na ukształtowanie się i okrzepnięcie demokracji w reżimach „szarej strefy” . Naukowcy twierdzą, że „szara strefa” polityczna jest okresem przejściowym, krótkotrwałym oraz w konsekwencji prowadzi do ewolucji reżimów w kierunku jednego z typów idealnych - demokracji lub autorytary$z \mathrm{mu}^{33}$. Natomiast G. O’Donnell określił demokrację delegatywną nowym typem istniejących reżimów, który nadal czeka na gruntowną analizę.

Postrzeganie reżimów hybrydalnych jako nowego typu politycznego napotykało na krytykę. W dużej mierze dotyczy to badaczy, którzy reprezentują paradygmat tranzytologiczny ${ }^{34}$. Za ojca tranzytologii uważa się amerykańskiego politologa Dankwarta Rustowa ${ }^{35}$. Przedmiotem jego badań był problem: w jaki sposób kraje przechodzą z jednego reżimu ku drugiemu i dlaczego jedne demokracje są nietrwałe, a drugie stają się stabilne i wciąż się rozwijają? Odrzucił on jednolite myślenie wobec uwarunkowań przejścia do demokracji, przez różne kraje w różnych etapach rozwoju. Uznał, że jedynym wspólnym warunkiem przejścia do demokracji jest narodowa jedność, gdyż eliminuje sytuacje, gdy w społeczeństwie możliwy jest rozłam. Politolog zaproponował pogląd alternatywny dla istniejącego (funkcjonalnego) podejścia, który określił jako "genetyczny” - odnoszący się do badań nad genezą zjawiska. Stworzył tzw. model przejścia od jednego reżimu ku drugiemu, określając go dynamicznym modelem przejścia, w którym wyodrębnił następujące etapy: faza przygotowawcza, faza przyjęcia działań, faza przyzwyczajenia ${ }^{36}$.

\footnotetext{
33 A. Antoszewski, R. Herbut, Systemy polityczne wspótczesnej..., s. 189-192.

${ }_{34}$ Рог. Г. Шипунов, Конщептуальні засади транзитологічнӧ̈ парадигми: історія становлення,

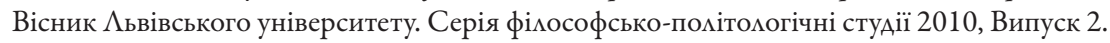

35 D.A. Rustow, Transition of Democracy: Toward a Dynamics Model, Comparative Politics 1970, vol. 2, nr 3, s. 337-363.

$36 \mathrm{~W}$ pierwszym etapie dochodzi do walki zróżnicowanych grup społecznych. Jej głównym wynikiem jest polaryzacja społeczeństwa, ograniczona narodową jednością. Podczas drugiej fazy część politycznych liderów dojrzewa do decyzji, by uznać zróżnicowanie i zinstytucjonalizować niektóre fundamentalne mechanizmy demokracji (prawa wyborcze, wolne wybory). Zdaniem Ru-
} 
Alternatywą do dynamicznego modelu może być zaproponowany przez rosyjskiego badacza Władymira Gelmana ${ }^{37}$ model przejścia z otwartym finałem, w którym dokonał rozróżnienia faz tranzycji: osłabienie poprzedniego reżimu, rozpad, niezdecydowanie, wyjście z niezdecydowania (ustanowienie nowego reżi$\mathrm{mu})$ oraz konsolidacja nowego reżimu ${ }^{38}$.

Nie można nie zgodzić się z poglądem, że reżimy hybrydalne należy traktować wyłącznie jako etap przejściowy w sytuacji, gdy w państwie dokonała się tranzycja systemowa i z powodzeniem zastosowano konsolidację nowego reżimu. Czy w przypadku, gdy tranzycja nie zakończyła się powodzeniem, a państwo nadal balansuje między demokracją a autorytaryzmem, uzasadnionym jest twierdzenie, że reżim hybrydalny nie jest przejściowy? Roman Bäcker podkreśla, że w przypadku rozróżnienia między systemami demokratycznymi a niedemokratycznymi, model abstrakcyjny typów hybrydalnych nie ma zastosowania. Za przykład podaje polskie wybory z 4 czerwca 1989 r. Postawienie pytania o demokratyczny przebieg wyborów powoduje, że nie znajdujemy jednoznacznie brzmiącej odpowiedzi. Brak jednoznaczności wobec tego casusu przekonuje, że nie jest wystarczającą odpowiedzią fakt, że wybory były demokratyczne w 35\% (gdyż tyle mandatów poselskich można było obsadzić w drodze demokratycznych wyborów). Istotnym wydaje się to, że na skutek wspomnianych wyborów nastąpiło przyjęcie przez polski naród suwerenności ${ }^{39}$.

stowa jest to konsensus w stosunku do reguł gry, pierwszy kompromis elit w nowej fazie przejścia. Staje się on kluczowym momentem demokratyzacji, ponieważ otwiera perspektywę rozwiązania istniejących i przyszłych problemów za pomocą demokratycznych narzędzi. W ostatniej fazie odbywa się przystosowanie elit politycznych oraz społeczeństwa do nowych demokratycznych reguł funkcjonowania państwa, procedur oraz wartości. Model ten, zdaniem autora może być stosowany jako narzędzie do interpretacji i rozumienia samego procesu przekształcenia się reżimu politycznego, gdyż pozwala uzmysłowić, jak dochodzi do owej ewolucji. Niezbędnym wydaje się być precyzyjne spojrzenie w jaki sposób dochodzi do zmiany i określenie warunków koniecznych do spełnienia oraz uwzględnienie czynnika czasowego.

37 В. Гельман, Трансформация в России: политический режим и демократическая оппозиция, Москва 1999.

${ }^{38}$ Zgodnie z modelem W. Gelmana tranzycja systemowa to przejście od jednego skonsolidowanego reżimu ku drugiemu. Etap przejściowy związany jest z brakiem konsolidacji reżimu politycznego, co zdaniem badacza, jest najistotniejszą cechą etapu przejściowego, która wyróżnia go spośród innych zmian w reżimie politycznym. Zaletą modelu przejścia z otwartym finałem jest uporządkowana struktura faz przejścia, to znaczy rozgraniczenie upadku poprzedniego i wprowadzenie drugiego oraz tzw. faza niezdecydowania: okres gdy np. państwo nie jest już autorytarytarne, ale nie jest jeszcze demokratyczne.

39 R. Bäcker „Okragty stót” - od totalitaryzmu do demokracji?, Athenaeum. Polskie Studia Politologiczne 2009, nr 22, s. 131-138; idem, Nietradycyjna teoria polityki, Toruń 2011, s. 14-16; idem, O znaczeniu kategorii typu idealnego, [w:] Czym jest teoria w politologii?, red. Z. Blok, Warszawa 2011, s. 209. 
R. Bäcker neguje fenomen reżimów hybrydalnych, ponieważ uważa, że w jednym państwie nie może istnieć dwóch suwerenów. Zgodnie z klasyczną definicją demokracji jako stanu suwerenności narodu posiadającego prawo dokonywania alternacji władzy, suwerenem będzie naród. W przypadku typu antynomicznego (reżimu autorytarnego), atrybut alternacji władzy będzie należeć do innego suwerena - burokracji bądź struktur siłowych ${ }^{40}$. Jak słusznie zauważa autor, powstaje pytanie czy w tym przypadku, gdy uznamy że istnieją reżimy hybrydalne, możliwy jest stan pośredni dotyczący suwerena, który dokonuje alternacji władzy? Czy za taki stan pośredni możemy uznać istnienie dwóch suwerenów? Udzielając odpowiedzi na to pytanie R. Bäcker podkreśla, że istnieją nieskonsolidowane systemy, w których pojawiają się aktorzy o innej mechanice działania niż typowy dla danego typu suwerenności, ale to nie oznacza jeszcze istnienia dwóch suwerenów. Dlatego też, jego zdaniem, reżimy hybrydalne skupiające w sobie cechy zarówno demokracji jak i autorytaryzmu, czyli posiadające jednocześnie dwóch suwerenów nie istnieją.

Koniecznym wydaje się być odniesienie do konkretnych przykładów prezentujących państwa w których na pewnym etapie rozwoju istniało dwóch suwerenów. Moim zdaniem najlepszym przykładem do analizy możliwości funkcjonowania w ramach jednego państwa dwóch suwerenów będzie sytuacja, w której dochodzi do przemian w państwie za pomocą rewolucyjnych metod. Za taki przykład dwuwładzy w państwie może można uznać m.in. Rosję w 1917 r. lub Francję podczas rewolucji francuskiej (1789-1799). Rozpatrując funkcjonowanie systemu politycznego Rosji (okres rewolucji lutowej i październikowej), po abdykacji rosyjskiego cara Mikołaja II ukształtował się system rządów dwóch podmiotów Rządu Tymczasowego, w skład którego weszła burżuazja i ziemiaństwo oraz Piotrogrodzkiej Rady Delegatów Robotniczych i Żołnierskich. Pierwszy powstał na skutek rewolucji lutowej i miał sprawować władzę w miejsce obalonego caratu, co nie zmienia faktu, że wciąż duże wpływy posiadała Rada Piotrogradzka. Świadczy to o dwuwładzy w ówczesnej Rosji. Po dokonanym przez bolszewików na czele z Włodzimierzem Leninem przewrocie politycznym w nocy 26 października 1917 r., po zdobyciu Pałacu Zimowego, doszło do obalenia Rządu Tymczasowego oraz przejęcia władzy przez Radę. Wydarzenie to zakończyło okres dwuwładzy w państwie rosyjskim ${ }^{41}$.

40 Zob. Idem, Podstawowe kategorie teoretyczne autorytaryzmu, [w:] Przywództwo, elity i transformacje w krajach WNP. Problemy metodologii badań, red. T. Bodio, t. 1, Warszawa 2010, s. 67-85; idem, Reżimy hybrydalne, [w:] Studia nad wspótczesnymi systemami politycznymi. Podmioty i procesy demokratyczne, red. J. Juchnowski, R. Wiszniowski, Toruń 2014, s. 37-46.

${ }^{41}$ R. Pipes, Rewolucja Rosyjska, Warszawa 2014. 
Należy także zwrócić uwagę, że R. Bäcker buduje swoje rozważania na poziomie teoretycznym, przez normatywne postrzeganie demokracji i autorytaryzmu (pryzmat suwerenów w tych reżimach). Tym samym neguje istnienie reżimów hybrydalnych. Moim zdaniem nie do końca potwierdza to tezę, że reżimy hybrydalne nie istnieją. W tym przypadku koniecznym wydaje się przeprowadzenie kompleksowych empirycznych badań. Możemy zastanawiać się nad tym czy fakt przeprowadzenia regularnych wyborów i na ich podstawie wyłonienie władz świadczy o tym, że naród jest suwerenem, a zatem mamy do czynienie z systemem demokratycznym? Czy nie należałoby zastanowić się nad tym w jaki sposób odbywa się wymiana elity rządzącej i czy możemy to zjawisko rozpatrywać w kategoriach alternacji władzy? W związku z tym jakie warunki dla alternacji władzy zostały zagwarantowane? W badaniach nad reżimami hybrydalnymi koniecznym jest stworzenie narzędzia badawczego, przez wypracowanie modelu teoretycznego, którego wiarygodność należy sprawdzić w badaniach empirycznych.

Zaprezentowane wybrane koncepcje dotyczące kategorii teoretycznej hybrydy demokratyczno-autorytarnej przyczyniły się do próby stworzenia własnej definicji reżimów hybrydalnych. Definiuję je jako państwa posiadające cechy istotnościowe zarówno demokracji i autorytaryzmu, to znaczy przez bilans demokratycznych standardów z narzędziami autorytarnymi (w taki sposób, że żaden z typów idealnych nie jest w tym przypadku dominującym). Proces ewolucji między antynomicznymi punktami continuum jest długotrwały (i nie doprowadza w konsekwencji do ewolucji w jeden z reżimów politycznych), a także żaden z aktorów uczestniczących w życiu politycznym (organy władzy, naród, organizacje pozarządowe) nie dążą do zmiany systemu drogą rewolucyjnych zmian.

\section{Badanie reżimów hybrydalnych}

Istotnym wydaje się stworzenie narzędzi, które pozwolą z jednej strony zbadać czy dany reżim jest hybrydalny oraz zbudować model teoretyczny. G. Szypunow proponuje badać reżimy hybrydalne za pomocą dziesięciu indykatorów (wskaźników) ${ }^{42}$ tzw. cech istotnościowych reżimu hybrydalnego, które dają możliwość odniesienia czy ten lub inny reżim można określić jako hybrydalny:

${ }^{42}$ Г. Шипунов, Теоретико-методологічні..., s. 95-101; idem, Теоретико-методологічні засади дослідження переходу від авторитаризму до демократї країн Центрально-Східної Європи (на прикладі України), [w:] Rozwoj polityczny panstw Europy Środkowej i Wschodniej, red. Z. Białobłocki, A. Romanyuk, Kutno 2012, s. 131-143. 
1. Mimo przeprowadzenia regularnych wyborów, zasada wolnych i uczciwych wyborów, zostaje zachwiana przez: a. pozbawienie części społeczeństwa możliwości uczestnictwa w wyborach (np. na podstawie pochodzenia etnicznego); b. pozbawienie i ograniczenie prawa uczestnictwa w wyborach, partii opozycyjnych oraz tych kandydatów, którzy mogą stać się realną konkurencją w wyborach dla partii rządzącej i/lub kandydata władzy; c. brak równych zasad prowadzenia kampanii wyborczej (np. ograniczenie dostępu opozycji do mediów lub stosowanie kampanii negatywnej wobec opozycji); d. wykorzystanie administracyjnego resursu oraz falsyfikacji wyników wyborów dla zagwarantowania wygranej partii/kandydata władzy. Politolog stosuje do każdego z indykatorów abrewiaturę, w tym przypadku będą to NW - naruszenia wyborcze.

2. W systemie władzy państwowej dominującą władzę posiada egzekutywa (personifikowana przeważnie w osobie prezydenta), który próbuje podporządkować sobie władzę ustawodawczą i sądowniczą. Natomiast w odróżnieniu od reżimów autorytarnych (gdzie egzekutywa i władza sądownicza są mu całkowicie podporządkowane) parlament stanowi ważne centrum opozycji reżimu, a władza ustawodawcza posiada uprawnienia, które pozwalają wydawać wyroki ograniczające niekonstytucyjne działania władzy wykonawczej (DWW - dominacja wykonawczej władzy).

3. Osłabienie formalnych instytucji demokratycznych, przez nielegitymizowane nieformalne podmioty i zachowania, takie jak np. klanowość, korupcja (NI - nieformalne instytucje).

4. Wojsko, organy państwowe formalnie przebywają pod kontrolą społeczeństwa, jednak elita rządząca posiada uprawnienia ich wykorzystania (nie tak jawnie jak w reżimach autorytarnych) w walce ze swoimi oponentami (SS - struktury siłowe).

5. System partyjny formalnie jest wielopartyjny, wszystkie partie aktywnie uczestniczą w procesie wyborczym na poziomie regionalnym oraz krajowym, jednak są stosowane ograniczenia wobec ugrupowań stanowiących tzw. zagrożenie dla partii władzy oraz nie mają one wpływu na kształtowanie się rządu (SP - system partyjny).

6. Funkcjonowanie organizacji społecznych przy jednoczesnych próbach państwa kontrolowania ich powstawania i funkcjonowania, w celu neutralizacji tych, które mogą stanowić realne zagrożenie dla władzy (OS - organizacje społeczne).

7. Działalność partii i grup opozycyjnych nie jest prześladowana, ale ich możliwości zdobycia władzy są znacznie ograniczone (ODO - ograniczona działalność opozycji). 
8. Państwo formalnie gwarantuje obywatelom prawo do alternatywnej informacji, media nie są cenzurowane i mogą krytykować działania władzy, jednak w rzeczywistości media masowe są zależne od egzekutywy - ona wyznacza poziom i kierunek krytyki wobec siebie, a także reguluje dostęp opozycji do nośników medialnych ( $\mathrm{NnM}$ - nacisk na media).

9. Brak ideologii, jednak w tych reżimach gdzie autorytarny czynnik jest zarysowany w znacznej mierze może przejawiać się pewien typ mentalności, wiąże się to z powstaniem tzw. wspólnego interesu narodu, państwa; wyznacznikiem owego interesu ogłasza się prezydent, którego określa się jako ojca nacji (IiM - ideologia i mentalność).

10. Kultura polityczna łączy w sobie elementy autorytarnej i demokratycznej (MKP - mieszana kultura polityczna).

Ukraiński badacz zaznacza, że analizując reżimy hybrydalne w ramach tranzytologicznego podejścia, w większości przypadków przez tranzyt rozumie się przejście od jednego ku drugiemu typowi idealnemu (od autorytaryzmu do demokracji tzw. klasyczny model przejścia). Wówczas gdy inne rodzaje politycznych reżimów, które powstają po rozpadzie autorytarnego systemu, są traktowane jako samowystarczalne rezultaty przekształcenia, w pewnym sensie stanowi to przystanek państw, które nie są już autorytarnym reżimem, a nie są jeszcze państwem demokratycznym ${ }^{43}$. Dlatego badacz wykorzystuje model przejścia z otwartym finałem W. Gelmana, który daje możliwość analizy tranzytu nie jako etap przejściowy, lecz jako polityczny reżim hybrydalny. Wyniki transformacji autorytarnych reżimów można interpretować za pomocą continuum demokracji i autorytaryzmu, gdzie autorytaryzm oznacza regres do starego reżimu lub ustanowienie nowej dyktatury, a demokracja - końcowy etap przejścia między owymi typami idealnymi. Tu znajdują się rożnego rodzaju reżimy hybrydalne.

G. Szypunow opracował metodę analizy przynależności konkretnego państwa do reżimów hybrydalnych za pomocą wyżej wymienionych indykatorów i wprowadził dwie skale. Pierwsza pomaga określić czy konkretny reżim jest hybrydalny, gdy w warunkach konkretnego reżimu pewien indykator „sprawdza się”, to uzyskujemy „1” jeśli nie to „0”, tak więc maksymalna liczba punktów, które może uzyskać badane państwo to „10” (co odpowiada czystemu hybrydalnemu reżimowi), i odpowiednio minimalna „0", co świadczy o tym że dany reżim nie jest hybrydalny lecz autorytarny lub demokratyczny. W przypadku, gdy państwo uzyska wynik

43 Г. Шипунов, Єврастичий потенціал поняття „гібридний політичний режим” в контексті дослідження перехіднх процесів на пострадянському просторі, [w:] Transformacje ustrojowe w Europie Środkowej i Wschodniej, red. Z. Białobłocki, A. Romanyuk, Kutno 2012. 
od 1 do 9 można mówić o typie reżimu hybrydalnego. Politolog dokonał określenia skali demokracji i autorytaryzmu, polegającej na podliczaniu „+” (plusów) stanowiących cechy demokracji, oraz „-" (minusów) stanowiących elementy państwa autorytarnego. W ten oto sposób $(+10)$ to demokracja, $(-10)$ autorytaryzm, od (+9) do (+5) hybrydalny reżim polityczny demokratycznej sytuacji, w którym przeważają demokratyczne elementy, na osi continuum znajdujące się blisko typu idealnego demokracji, od (-9) do (-5) reżim hybrydalny autorytarnej sytuacji, w którym przeważają elementy autorytarne, bliżej pola autorytaryzmu, od (+4) do (-4) reżimy hybrydalne ( $w$ węższym znaczeniu), to znaczy zbliżone od czystego reżimu hybrydalnego, znajdujące się pośrodku osi continuum. Reżim znajdujący się między (+4) i 0 badacz określa jako reżim hybrydalny z tendencjami ewolucji w stronę demokracji, drugi interwał między 0 i (-4) odpowiednio jako reżim hybrydalny z tendencjami ewolucji w stronę autorytaryzmu. Jeśli państwo osiąga jednocześnie wynik $(+5)$ i $(-3)$ to końcowy wynik stanowi $(+2)^{44}$.

Rysunek 1. Gradacja reżimów hybrydalnych na osi continuum

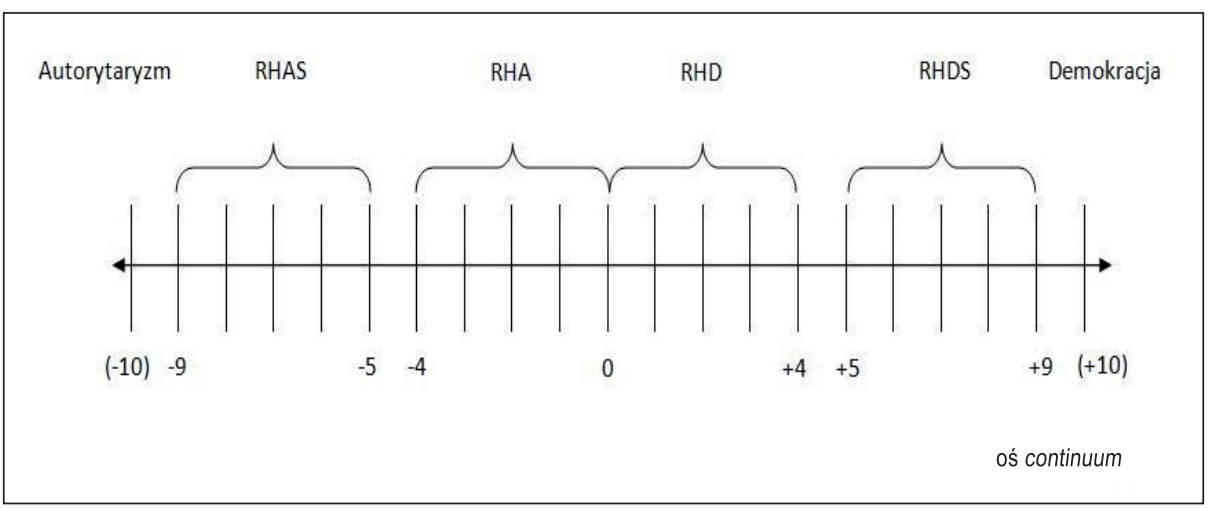

Źródło: Opracowanie własne na podstawie: Г. Шипунов, Теоретико-методологічні..., s. 95-101.

RHAS - reżim hybrydalny autorytarnej sytuacji

RHA - reżim hybrydalny z tendencjami ewolucji w kierunku autorytaryzmu

RHD - reżim hybrydalny z tendencjami ewolucji w kierunku demokracji

RHDS - reżim hybrydalny demokratycznej sytuacji

Należy podkreślić, że zaletą zaproponowanego sposobu badań reżimu hybrydalnego jest stworzenie wskaźników reżimu hybrydalnego, za pomocą których można podjąć się analizy czy dany reżim jest hybrydalny, czy nie. Także G. Shy-

${ }^{44}$ Г. Шипунов, Теоретико-методологічні..., s. 95-101. 
punow proponuje zastosować dany model do analizy tego jaki to jest reżim hybrydalny, przez ustalenie czy dominują w nim cechy demokracji, czy autorytaryzmu. W tym przypadku, nie podzielam zdania badacza, gdyż moim zdaniem podejście to pozwoli zbadać tylko fakt z jakim reżimem mamy do czynienia, nie pozwala na kompleksową analizę tego zjawiska pod względem jakościowym.

Jako alternatywę proponuję zastosować badanie reżimów za pomocą metody typów idealnych ${ }^{45}$ Maxa Webera $^{46}$, przez uzasadniony dobór cech istotnościowych dla demokracji i autorytaryzmu ${ }^{47}$, czyli stworzenie pewnego modelu teoretycznego $^{48}$ i sprawdzenie na konkretnych przypadkach w jakim stopniu ten katalog cech dla demokracji bądź autorytaryzmu jest realizowany ${ }^{49}$, umożliwi to zbadanie czy mamy do czynienie z reżimem demokratycznym, autorytarnym czy mieszanym. W ten sposób należy, przez zastosowanie definicji dla demokracji i autorytaryzmu, wyodrębnić cechy konstytutywne dla danych reżimów. W przypadku demokracji $\mathrm{w}$ państwie istotnym m.in. będzie zagwarantowanie zasady alternacji władzy. Natomiast w reżimie autorytarnym będziemy mieć do czynienia z odwrotną sytuacją, gdyż rządzący będzie starać się zachować monopol władzy. Co w przypadku gdy te wskaźniki nie będą realizowane w pełni ani w przypadku demokracji, ani autorytaryzmu tj. częściowe zagwarantowanie zasady alternacji władzy przez regularne wybory, przy jednoczesnych ograniczeniach możliwości zdobycia władzy przez opozycję (przez ograniczenia prowadzenia kampanii wyborczej, dostępu do mediów) ${ }^{50}$ ? Badanie reżimów hybrydalnych w kontekście cech istotnościowych

${ }^{45}$ Należy zwrócić uwagę, że samo pojęcie typy idealne wskazuje na to, że są to modelowe rozwiązania, dlatego bardzo trudnym jest odnalezienie realnych przykładów, które by spełniały wszystkie cechy typów idealnych. Bardziej uzasadnionym wydaje się badanie tego w jakim stopniu są one do nich zbliżone. Dlatego typy idealne należy traktować jako narzędzie w badaniach, a nie próbę karagoryzacji.

${ }_{46}$ M. Weber, Obiektywność poznania w naukach społecznych, [w:] Problemy socjologii wiedzy, wyb. i oprac. A. Chmielecki, Warszawa 1985, s. 81-83, 88; idem, Szkice z socjologii religii, Warszawa 1995.

${ }^{47}$ Cechy istotnościowe, konstytutywne lub naczelne zasady ustrojowe są to zawarte w konstytucjach normy danego ustroju państwowego. Określają one cechy danego ustroju oraz wyrażają podstawowe wartości konstytucyjne. Wśród nich można wymienić m.in.: zasadę podziału władzy i równowagi władzy, zasadę suwerenności narodu, pluralizmu politycznego, demokratycznego państwa prawnego, Polskie prawo konstytucyjne, red. W. Skrzydło, Lublin 2004, s. 107.

${ }^{48}$ S. Ossowski, Kategoria typu idealnego w konstruowaniu modelu teoretycznego, [w:] Czym jest teoria...

${ }^{49}$ Metodę omówiono w: K. Kruk, Metodologiczne refleksje w politologicznych badaniach empiryczno-teoretycznych, Athenaeum. Polskie Studia Politologiczne 2014, nr 43, s. 116.

${ }^{50}$ Por. M. Prokop, I. Galewska, The Amendment of the Ukrainian Electoral Law and the Principle of Alternation in Power (Parliamentary Election 2012), Athenaeum. Polskie Studia Politologiczne 2013, nr 40, s. 19-30. 
typów idealnych wymaga kompleksowych badań konkretnych przypadków reżimów politycznych co umożliwi egzemplifikację wyżej przedstawionej tezy ${ }^{51}$. Założenia tego typu nie były jednak przedmiotem niniejszego artykułu.

\section{Podsumowanie}

Zagadnienie reżimów hybrydalnych niejednokrotnie było poruszane przez wielu badaczy w Polsce i zagranica, spowodowało to ukształtowanie się wielu koncepcji oraz prób ich definiowania. W prezentowanym artykule podjęłam się zadania analizy teoretycznych i metodologicznych podstaw badań nad reżimami hybrydalnymi, znajdującymi się między demokracją a autorytaryzmem oraz odnalezienia odpowiedzi na pytanie w jakim stopniu kategoria reżimów hybrydalnych (hybryda demokratyczno-autorytarna), może być postrzegana jako nowy typ reżimów politycznych, a w jakim należy ją traktować wyłącznie jako jeden z etapów tranzycji systemowej?

Należy zaznaczyć, że fenomen hybrydy demokratyczno-autorytarnej polega na tym, że proces ewolucji od jednego typu idealnego ku drugiemu ma charakter długotrwały, często przybiera formę nieustanego poruszania się po osi continuum. Jednakże w wielu przypadkach państwa z powodzeniem realizują przekształcenie systemu politycznego. Rozstrzygając postawiony we wstępie problem badawczy doszłam do wniosku, że reżimy hybrydalne często należy traktować jako etap tranzycji systemowej, natomiast nie powinno się negować faktu, że długotrwałe balansowanie między demokracją a autorytaryzmem może stać się podstawą do określenia reżimów hybrydalnych jako nowego typu reżimów politycznych.

Moim zdaniem całkowite negowanie możliwości istnienia reżimów hybrydalnych, eliminuje sam proces wprowadzania, utrwalania w państwie znajdującym się na osi między typami idealnymi mechanizmów i standardów nowego reżimu. Tym samym nie uwzględnia się założenia, iż może ono nieustannie ewoluować w kierunku jednego lub drugiego typu idealnego, w konsekwencji nie doprowadzając do utrwalenia któregoś z nich. Potwierdzenie tego, że reżimy hybrydalne można traktować jako nowy typ reżimów, potrzebuje kompleksowych empirycznych badań, gdyż nie jest możliwe postawienie takiej tezy na podstawie teoretycznych ujęć abstrakcyjnej kategorii demokratyczno-autorytarnej.

51 Zob. М. Прокоп, Трансформауія політичної системи України: баланс на грані демократії і авторитаризму, [w:] Інформачійне Забезпечення Транскордонного Співробітнищтва Украӥни, Ауцьк 2014, t. 2. 